\title{
Complexity affects habitat preference and predation mortality in postlarval Penaeus plebejus: implications for stock enhancement
}

\author{
Faith Ochwada ${ }^{1,2, *}$, Neil R. Loneragan ${ }^{3}$, Charles A. Gray $^{4}$, Iain M. Suthers ${ }^{1,2}$, \\ Matthew D. Taylor ${ }^{1,2}$ \\ ${ }^{1}$ Evolution and Ecology Research Centre, School of Biological, Earth and Environmental Science, \\ University of New South Wales, New South Wales 2052, Australia \\ ${ }^{2}$ Sydney Institute of Marine Science, Building 22, Chowder Bay Road, Mosman, New South Wales 2088, Australia \\ ${ }^{3}$ Centre for Fish and Fisheries Research, School of Biological Sciences and Biotechnology, Murdoch University, South Street, \\ Murdoch, Western Australia 6150, Australia \\ ${ }^{4}$ Cronulla Fisheries Research Centre, NSW Primary Industries Science and Research, PO Box 21, Cronulla, \\ New South Wales 2230, Australia
}

\begin{abstract}
Global attempts to offset declines in fishery populations through stock enhancement have had varied levels of success due to the absence of preliminary studies to determine which habitats best support release species and the mechanisms controlling their distribution. Habitat preference was examined as a possible mechanism driving distribution of postlarval Penaeus plebejus, a current candidate prawn for stock enhancement in Australia. Occupancy of complex (artificial macrophyte) and simple (bare sand and mud) habitats by postlarvae was compared in the presence and absence of a choice between the habitats. Predation mortality was also compared amongst these habitats. P. plebejus settled into the different habitats randomly during the night, but actively selected macrophyte over the simple habitats during the day. Mortality caused by the predatory fishes Centropogan australis and Acanthopagrus australis was higher in simple habitats than in complex habitats, but was similar across habitats when large penaeid prawns, Metapenaeus macleayi (which are tactile rather than visual feeders), were used as predators. Postlarvae may select macrophyte habitats during the day to lower predation risk, but because nighttime foraging efficiency is reduced in their predators, which are primarily visual hunters, this may preclude the need of postlarvae to obtain shelter in macrophyte habitats at night. Predation mortality of stocked P. plebejus may be minimized by releasing postlarvae directly into macrophyte habitats. Studies such as these must precede all stock enhancement attempts because they identify optimal release strategies and allow ecological and financial costs of enhancement to be weighed against projected benefits, and thereby assess the practicality of enhancement as a management option.
\end{abstract}

KEY WORDS: Stock enhancement · Habitat - Predation - Macrophytes · Fisheries management · Prawns $\cdot$ Penaeid $\cdot$ Eastern Australia

Resale or republication not permitted without written consent of the publisher

\section{INTRODUCTION}

Global declines in fishery stocks due to overexploitation and habitat fragmentation (Pikitch et al. 2004, Anderson et al. 2008) have regenerated interest in stock enhancement as a means of replenishing depleted populations through the release of hatchery reared individuals into the wild (Rothlisberg et al. 1999). However, this management approach is rarely successful and is often characterized by low survival rates 
amongst released individuals (Blankenship \& Leber 1995, Grimes 1998). Historically, the failure of enhancement events has been caused by impetuous hatchery production and indiscriminate releases that have hampered development of a scientific basis for how best to optimize stock enhancement or whether this approach should even be used (Leber 2002). Previous assessment of the ecological factors that affect the survival and growth of stocked species can dramatically reduce post-release mortality and can help evaluate the practicality of enhancing a species within a given system (Crowl et al. 1992, Eades \& Steinkoenig 1995, Einum \& Fleming 2001). One such ecological factor is the capacity of different habitats to support a stocked species (Rothlisberg 1998), which is partly determined by the species' habitat preference and habitat related predation mortality. Our study evaluates these determinants of carrying capacity for the eastern king prawn Penaeus plebejus Hess, 1865, which has been recently identified as a candidate for stock enhancement in New South Wales, Australia.

Penaeus plebejus is one of the most economically important penaeid prawns found in Australia, and has an annual commercial production valued at $\sim$ AUS $\$ 40.5$ million (Courtney 2002) and a significant recreational fishery (Ives \& Scandol 2007). High exploitation rates, habitat loss and recruitment variability have led to significant declines in the abundance of many penaeid species (Rothlisberg et al. 1999) and trial stock enhancement has been assessed in different regions to address these factors with limited success (Su \& Liao 1999, Loneragan et al. 2007). Understanding which types of habitats best support these species and the mechanisms controlling their habitat use is critical to improving the success of future enhancement efforts for penaeids.

Penaeid prawns show a high degree of association with distinct habitats (e.g. Dall et al. 1990a). For some species, structurally complex habitats such as macrophyte beds generally support more individuals (Heck \& Thoman 1984, Hill \& Wassenberg 1993), especially during their juvenile stages (Haywood et al. 1995). Penaeus plebejus juveniles are usually more abundant in seagrass beds than adjacent bare habitats at small spatial scales (Young 1978), and their densities are often positively correlated with seagrass cover (Skilleter et al. 2005). Similar relationships in other penaeids have been attributed to greater protection from predators, increased feeding resources or a combination of these factors (Bell \& Westoby 1986, Liu \& Loneragan 1997). Despite abundant data supporting these theories in other species (e.g. Loneragan et al. 1997, Primavera 1997, Macia 2004), it is still unclear whether the immediate cause of higher densities of $P$. plebejus within macrophyte beds is simply a result of lower post-settlement mortality (via predation or starvation) within this habitat or an innate preference for macrophyte beds during settlement. If $P$. plebejus postlarvae show a preference for structured habitats, then behavioral mechanisms could be influencing their distribution before post-settlement mortality through predation or starvation. Although other factors that are distinct from behavioral or interactive processes between species may also influence the distribution of $P$. plebejus amongst habitats (e.g. small scale habitatrelated variation in hydrodynamics may allow more postlarvae to settle more frequently in particular habitats), the research presented here focuses on the influence of preference and predation mortality.

We investigate whether the distribution of Peneaus plebejus amongst habitats is a result of active selection during its postlarval phase, and whether selection differs between day and night by comparing selection of macrophyte, bare sand and bare mud habitats during these diel periods. The habitats examined represent the most prevalent habitat types in local estuaries where enhancement of $P$. plebejus is being considered. They also differ in characteristics (other than complexity) that may influence a postlarva's ability to use them. For example, the anoxic nature of mud and its smaller pore spaces relative to sand may limit respiration in postlarvae (Williams 1958, Mnaya et al. 2006). In contrast, the high organic content of mud compared with sand may increase food supply within muddy habitats (Williams 1958, Van Luijn et al. 1999, Mnaya et al. 2006). Accordingly, some penaeid species occur more frequently on sandy substratum than muddy substratum (e.g. P. duorarum), whilst other penaeids exhibit the opposite pattern (e.g. P. aztecus and P. setiferus) (Williams 1958). This research also tests whether postlarval predation mortality differs between macrophyte, sand and mud habitats. We conclude by considering the implications of our results in relation to stock enhancement, providing a scientific basis for releasing $P$. plebejus into estuarine systems.

\section{MATERIALS AND METHODS}

Rearing and transport of Penaeus plebejus. Hatchery-reared Penaeus plebejus postlarvae were produced by a commercial supplier, using wild brood stock collected off the central east coast of Australia (between $30^{\circ} 16^{\prime} 49^{\prime \prime} \mathrm{S}, 153^{\circ} 12^{\prime} 6^{\prime \prime} \mathrm{E}$ and $24^{\circ} 45^{\prime} 6^{\prime \prime} \mathrm{S}$, $153^{\circ} 1^{\prime} 22^{\prime \prime} \mathrm{E}$ ). At $17 \mathrm{~d}$ old (carapace length [CL] $\sim 4 \mathrm{~mm}$ ), the postlarvae were transferred to a flowthrough, coarse-filtered aquarium facility in Cronulla, New South Wales $\left(34^{\circ} 4^{\prime} 21^{\prime \prime} \mathrm{S}, 151^{\circ} 08^{\prime} 56^{\prime \prime} \mathrm{E}\right)$ by air and road in foam boxes containing 101 of water within sealed plastic bags. Postlarvae were acclimated to 
water conditions in the aquaria (11.5 mg dissolved oxygen [DO] $\mathrm{l}^{-1}, 12.3^{\circ} \mathrm{C}, 36.6$ salinity) by suspending the bags in an aquarium holding tank (100 l) for $40 \mathrm{~min}$. Postlarvae were fed hatchery feed pellets and kept in the holding tanks for a period of $3 \mathrm{~d}$ before the commencement of the habitat preference trials and for $9 \mathrm{~d}$ before the commencement of the aquaria based predation trials. During this time, tanks were siphoned every second day to clean out unconsumed food and waste. The predation trials were repeated in the field in Wallagoot Lake, New South Wales $\left(36^{\circ} 47^{\prime} 18^{\prime \prime} \mathrm{S}\right.$, $\left.149^{\circ} 56^{\prime} 31^{\prime \prime} \mathrm{E}\right)$. Postlarvae, $18 \mathrm{~d}$ old and CL $\sim 4 \mathrm{~mm}$, were transported to the field site from the hatchery as described previously. Field experiments commenced immediately after postlarvae had acclimated to the conditions within experimental cages suspended in the lake (7.8 $\mathrm{mg} \mathrm{DO} \mathrm{l}^{-1}, 24.3^{\circ} \mathrm{C}, 35.7$ salinity).

Habitat preference. The settlement patterns of Penaeus plebejus postlarvae into bare mud, bare sand and artificial macrophyte habitats were examined using a design similar to that described by Olabarria et al. (2002). Sand and mud were collected from a coastal bay near the aquaria facilities and placed in shallow bins to a depth of $4 \mathrm{~cm}$. Seawater was then added to the bins to submerge the substratum entirely. The substratum was 'aged' in a sunlit area with continuous air supply over a $7 \mathrm{~d}$ period to allow a film of biota to develop on the surface. The artificial macrophyte habitat consisted of AquaMat $^{\circ}$, a positively buoyant synthetic matting with a high microscopic surface area that is supplied divided into blades (shoots) (each blade was $\sim 15 \mathrm{~cm}$ high and $\sim 1.5 \mathrm{~cm}$ wide and there were $\sim 67$ blades per meter of AquaMat). AquaMat effectively simulates the blades and leaves of macrophytes in the wild (Arnold et al. 2005). At their base, the AquaMat blades were attached to weighted $30 \mathrm{~cm}$ lengths of the same synthetic matting. The AquaMat was placed within a natural, sunlit seagrass bed adjacent to the aquaria facilities for $21 \mathrm{~d}$ to facilitate colonization of epiphytes and a microbial film. Any macroinvertebrates that settled on the AquaMat during this time were located and removed before use in the experiment since these organisms may have included newly settled P. plebejus postlarvae from the wild and invertebrates capable of consuming the experimental postlarvae.

At the beginning of each experiment, each substrate type was established within 6 separate aluminum habitat trays $(15 \times 32 \times 4 \mathrm{~cm})$. Both mud and sand habitat trays were entirely covered with a $4 \mathrm{~cm}$ layer of their respective substrate types. When retrieved from the 'ageing' bins, these substrates were transferred to the habitat trays with minimal disruption to the surface layer to preserve the surface film of biota. Each macrophyte habitat tray had two $30 \mathrm{~cm}$ lengths of weighted
AquaMat base implanted into a $4 \mathrm{~cm}$ layer of sand, with the attached AquaMat blades (with equivalent shoot density of 837.5 shoots $\mathrm{m}^{-2}$ and a surface area of $1.88 \mathrm{~m}^{2} \mathrm{~m}^{-2}$ of substrate) emerging above the sand. Each tray had two $50 \mathrm{~cm}$ twine handles to allow the trays to be removed from the tanks upon completion of experiments.

In each of 3 independent experimental tanks (50 l, $55 \times 34 \times 25 \mathrm{~cm}$ ), one of each of the sand, mud and macrophyte habitat trays were placed along the tank (Fig. 1). These tanks were used to determine whether postlarvae occupied a particular habitat at higher densities when the alternative habitats were also available. In each experimental tank, 20 postlarvae were initially released over 1 tray only, either the sand, mud or macrophyte habitat tray. Three separate $50 \mathrm{l}$ tanks were used as controls, each containing 3 habitat trays of only 1 habitat type (Fig. 1). These tanks allowed us to attribute greater occupancy of a particular habitat to the active behavior of preference to habitat type, as they eliminated the possibility of confounding preference with other artifacts (e.g. varied accessibility among the habitats) that may cause a greater number of postlarvae to remain within a habitat. Twenty postlarvae were initially released over only one of the habitat trays present in each control tank. During release and for the first hour after release, each tray within each tank was segregated from adjacent trays with $1 \mathrm{~mm}$ mesh netting. After the first hour, the mesh netting was removed so that the postlarvae could access all trays within a given tank.

Six replicate trials $(n=6)$ of the experiment were conducted (with renewed postlarvae in each trial). The placement of habitat trays along each tank was alternated among replicate trials so that all possible arrangements (total of 6) of the 3 habitat trays in a single tank were used. Treatments were randomly assigned to each tank during each trial and indepen-

\section{Experimental tanks}

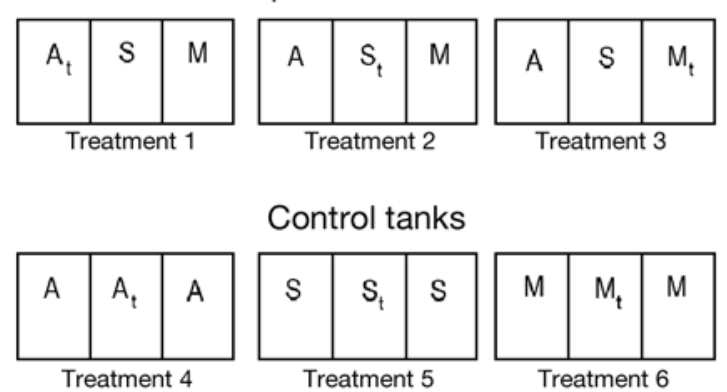

Fig. 1. Penaeus plebejus. Tanks used to test for preference of artificial macrophyte (A), bare sand (S) or bare mud (M) habitats by postlarval prawns. The subscript $t$ associated with $\mathrm{A}, \mathrm{S}$ and $\mathrm{M}$ indicates the habitat over which postlarvae were released at the beginning of the experiment for each tank 
dent habitat trays (with renewed substrate and seawater) were used for each trial. Postlarvae were initially released into each tank at 06:00 $\mathrm{h}$ and the experiment ran for $12 \mathrm{~h}$ in an artificially illuminated environment to simulate daytime conditions. After $12 \mathrm{~h}$, the habitat trays were segregated with the mesh netting, trays were removed from tanks and the number of postlarvae occupying each tray was counted. The entire series of trials was repeated in dark conditions (from 18:00 to 06:00 h) using new postlarvae and habitat trays.

Predation mortality. Laboratory experiment: Predation mortality of Penaeus plebejus postlarvae in sand, mud and macrophyte habitats was examined using adult eastern fortesque Centropogon australis (White, 1790) (9 to $10 \mathrm{~cm}$ total length [TL]), juvenile yellowfin bream Acanthopagrus australis (Owen, 1853) (12 to $15 \mathrm{~cm}$ TL) and late juvenile to sub-adult school prawns Metapenaeus macleayi (Haswell) (6 to $10 \mathrm{~cm} \mathrm{TL,} 3.5$ to $5 \mathrm{~cm} \mathrm{CL}$ ) as predators. Predators were sampled from the George's River, New South Wales (340' $11.62^{\prime \prime} \mathrm{S}$, $151^{\circ} 06^{\prime} 27.61^{\prime \prime} \mathrm{E}$ ) with an otter trawl and transported to the aquaria facilities in separate aerated $80 \mathrm{l}$ tanks where they were acclimated to aquarium conditions and released into a $2500 \mathrm{l}$ (fish species) or a $100 \mathrm{l}$ (M. macleayi) holding tank. Whilst in the holding tanks, the fish were fed commercially purchased prawn flesh every second day and the $M$. macleayi were fed a mixture of commercially purchased adult prawn flesh and hatchery pellets every second day. Tanks were siphoned every second day to remove unconsumed food and waste

Two $100 \mathrm{l}$ tanks (25 cm radius, $50 \mathrm{~cm}$ high) were prepared with sand habitat, 2 with mud habitat and 2 with macrophyte habitat. Each habitat was collected and 'aged' as described previously. The sand and mud habitat were established to a depth of $4 \mathrm{~cm}$ on the base of each of their respective tanks. Sand was added to the base of the macrophyte habitat tanks to a depth of $4 \mathrm{~cm}$ and three $40 \mathrm{~cm}$ lengths of fouled AquaMat were then implanted into the sand with attached $25 \mathrm{~cm}$ high AquaMat blades emerging above (equivalent to a shoot density of 409.5 shoots $\mathrm{m}^{-2}$ and a surface area of $1.53 \mathrm{~m}^{2} \mathrm{~m}^{-2}$ of substrate). One of the 2 tanks containing each habitat type was haphazardly assigned as the experimental tank and had 1 predator added to it at the beginning of each experimental trial. The remaining tank was the control tank and contained no predator. The control tanks were used to identify any variables other than predation that may cause mortality of postlarvae. There were 3 independent replicate tanks of each treatment and 2 replicate trials of the experiment $(n=6)$ were undertaken with each predatory species. Substrates, seawater and predators were renewed for each experimental trial and tanks were haphazardly re-assigned to a treatment before each trial.

At the beginning of each experimental trial, 20 postlarvae were released into each tank and left to settle for $2 \mathrm{~h}$, after which a single predator was added using a large fine-mesh dip net. The process of adding a predator to a tank was simulated in the control tanks by dipping an empty dip net that had previously contained a predator into the water for $10 \mathrm{~s}$. The predators were removed from the experimental tanks after $24 \mathrm{~h}$ with a dip net and each tank was drained of water to determine the number of postlarvae remaining.

Field experiment: Nine juvenile Centropogon australis (6 to $9 \mathrm{~cm}$ TL) obtained from Merimbula Lake, New South Wales (3653' 50.89" S, 14953'04.73" E) with a beach seine were used as predators. The predators were housed in 2 aerated tanks ( 50 l) for a period of $78 \mathrm{~h}$. During this time, the $C$. australis were fed commercially purchased adult prawn flesh every day. The water in each tank was renewed on a daily basis about $2 \mathrm{~h}$ after the predators had ceased feeding.

The field experiment was conducted in 6 cages (2 $\mathrm{mm}$ stretch mesh), each $1 \mathrm{~m}^{3}$ in size with an enclosed base, which were half-submerged in Wallagoot Lake. Sand, mud or macrophyte habitat were each added to 2 of the cages. Sand and mud were collected from Wallagoot Lake and deposited directly into the cages $5 \mathrm{~d}$ before the experiment began. The macrophyte habitat was prepared and established within the cages in the same manner and at similar quantities as described for the aquaria experiments, but the AquaMat was 'aged' in Wallagoot Lake for $38 \mathrm{~d}$ before the experiment. One of the cages containing each habitat type was haphazardly assigned as the experimental cage and the other was assigned as the control cage. There were 3 independent replicate cages for each treatment $(\mathrm{n}=3)$.

Forty minutes after 50 postlarvae were released into each field cage and acclimated to the conditions therein; a single Centropogon australis was added to each experimental cage by means of a dip net. The process was simulated within the control cages. After $5 \mathrm{~d}$, each cage was moved intact to the shoreline where its contents were emptied into a plastic container, preserved in formalin and transported to laboratory facilities. The $C$. australis from each experimental cage was captured and preserved separately. The contents of the containers were examined $3 \mathrm{wk}$ later within the laboratory to quantify the proportion of postlarvae remaining at the end of the experiment.

Statistical analyses. All statistical analyses were carried out in Stat Graphics Plus 5. Cochran's test was used to examine homogeneity of variances among treatments for each experiment. Where variances dif- 
fered significantly ( $p<0.05)$, the proportional data were arcsine transformed.

For the habitat preference experiments, a priori planned contrasts incorporated into a 1-way ANOVA (with 12 levels; each of macrophyte, sand or mud with the other habitats either present or absent in each of night and day conditions) were used to test the effects of habitat treatment on the proportion of postlarvae remaining within each release tray during the day and at night. Only the data from a single tray from each tank (the release tray) was used in the ANOVA, thus avoiding the problem of non-independence amongst treatments.

We predicted that the macrophyte habitat would be the habitat preferred by postlarvae and would be seen in either diurnal period. Three alternative hypotheses, which were tested using the a priori planned contrasts, had to be supported for each period (Table 1). The first hypothesis $\left(\mathrm{H}_{1}\right)$ stated that if released into a tray with one of macrophyte, sand or mud habitats and given a choice to move into 1 of the 2 alternative habitats (Treatments 1 , 2 and 3, respectively, in Fig. 1), fewer postlarvae would move out of the macrophyte tray compared with the sand and mud trays. $\mathrm{H}_{1}$ also predicted that when released into a macrophyte tray and given no choice of other habitats in which to move (i.e. when all thirds of a tank consisted of macrophyte trays) (Treatment 4 in Fig. 1), fewer postlarvae would actively move out of the macrophyte trayof-release compared with the number moving out of the release trays in Treatments 2 and 3 in Fig. 1. The last 2 hypotheses $\left(\mathrm{H}_{2}\right.$ and $\left.\mathrm{H}_{3}\right)$ predicted that more postlarvae would move out of sand and mud release trays, respectively, when the macrophyte habitat was also available (Treatments 2 and 3 in Fig. 1) compared with when each of the sand and mud habitats were available alone (Treatments 4 and 6 in Fig. 1). The residual mean

Table 1. Penaeus plebejus. Hypotheses used to test for habitat preference and examine effects of diel period on preference patterns. $n_{A_{t} i}, n_{S_{t} i}$ or $n_{M_{t} i}$ represent the number of postlarvae left at the end of the experiment in the habitat tray where they were initially released (artificial macrophyte $\left[\mathrm{A}_{t}\right]$, sand $\left[\mathrm{S}_{\mathrm{t}}\right]$ or mud $\left[\mathrm{M}_{\mathrm{t}}\right]$, respectively); $\mathrm{N}_{i}$ is the total number of postlarvae recovered from a treatment tank at the end of the experiment and $i=1$ to 6 indicates the treatment tank (see Fig. 1)

\begin{tabular}{|cc|}
\hline Alternative hypothesis & Test \\
\hline $\mathrm{H}_{1}$ & $\frac{n_{A_{t} 1}}{N_{1}}, \frac{n_{A_{t} 4}}{N_{4}}>\frac{n_{S_{t} 2}}{N_{2}}, \frac{n_{M_{t} 3}}{N_{3}}$ \\
$\frac{n_{S_{t} 2}}{N_{2}}<\frac{n_{S_{t}}}{N_{5}}$ \\
$\mathrm{H}_{2}$ \\
$\mathrm{H}_{3}$ \\
$n_{M_{t} 3}$ & $<\frac{n_{M_{t} 6}}{N_{6}}$ \\
\hline
\end{tabular}

squares (MS) used in the planned contrasts were taken from the omnibus 1-way ANOVA.

For the laboratory predation experiments, three 2-way ANOVAs were used to analyze the survival data for each predatory species separately. Both factors in the ANOVAs, habitat (3 levels: sand, mud or macrophyte) and predator treatment (2 levels: present or absent), were fixed. For the field based experiments, one 2-way ANOVA with the same fixed factors was used to analyze the survival data. Each ANOVA tested 2 alternative hypotheses that (1) proportion of surviving postlarvae within each habitat would be dependent on the presence or absence of predators, and (2) in the presence of predators this proportion would be higher in the macrophyte habitat compared with the sand and mud habitats. Where an interaction between predator treatment and habitat was detected, Tukey's HSD test was used to determine which treatments differed from each other.

\section{RESULTS}

\section{Habitat preference}

For the night and day experiments 100 and $99.4 \%$, respectively, of the postlarvae released into all tanks were recovered. Variances were homogeneous amongst all release trays used in the experiment (Cochran's test: $C=0.23, \mathrm{n}=6, k=12, \mathrm{p}>0.05$ ). Similar proportions of postlarvae remained in each habitat's release tray at night (ranging from 0.3 to 0.35 ), irrespective of whether postlarvae were given a choice of habitats to move into (Fig. 2). During the day, how-

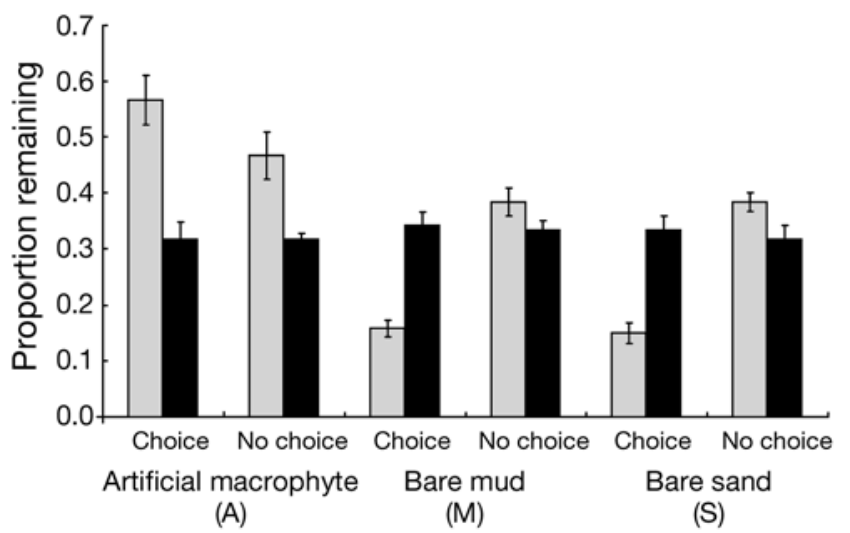

Fig. 2. Penaeus plebejus. Average $( \pm \mathrm{SE})$ proportion of postlarvae remaining in artificial macrophyte (A), bare mud (M) or bare sand (S) after release into each of these habitats either when each was present with equal amounts of the 2 alternate habitats also available (Choice) or when each habitat was the only habitat present (No choice). The plot contrasts the behavior of the postlarvae in simulated daytime (grey bars) and nighttime (black bars) conditions 
ever, release trays within the different treatment tanks had different proportions of postlarvae remaining in them (Fig. 2). The proportion was highest in the macrophyte release trays, irrespective of whether postlarvae were given alternative habitats to move into. Intermediate proportions remained in the sand and mud release trays when the alternative habitats were absent. The lowest proportions were observed in sand and mud release trays when the alternative habitats were also present. Consistent with this overall pattern, the planned contrasts revealed that $\mathrm{H}_{1}, \mathrm{H}_{2}$ and $\mathrm{H}_{3}$ were supported during the day, but not at night when there was no significant difference between the habitat treatments involved in each of the planned comparisons (Table 2, Fig. 2). With the exception of each of the sand and mud release trays that were available with no choice of alternative habitats, all daytime trays were dissimilar from their nighttime equivalents (Fig. 2).

\section{Predation mortality}

Whilst the treatments in the laboratory experiment in which Acanthopagrus australis were used as predators had homogenous variances (Cochran's test: $C=0.31$, $\mathrm{n}=6, k=6, \mathrm{p}>0.05$ ), variances were significantly different for the laboratory experiment in which Centropogon australis were used as predators (Cochran's test: $C=0.69, \mathrm{n}=6, k=6, \mathrm{p}<0.05)$. These data were consequently arcsine transformed to produce a data set with homogeneous variances (Cochran's test: $C=0.29$, $\mathrm{n}=6, k=6, \mathrm{p}>0.05)$. There was a significant interaction between habitat and predator presence/absence in the $A$. australis and $C$. australis laboratory trials (Table 3). Survival of postlarvae was close to $100 \%$ in all control tanks and varied among habitats in the experimental tanks, being significantly higher (55 to $60 \%$ survival) in the macrophyte habitat tanks com- pared with the sand and mud tanks (15 to 25\% survival; Table 3, Fig. 3a,b). When Metapenaeus macleayi were used as predators in the laboratory, variances were not significantly different among treatments (Cochran's test: $C=0.39, \mathrm{n}=6, k=6, \mathrm{p}>0.05$ ). There was also no significant interaction between habitat and predator presence/absence (Table 3, Fig. 3c). Although survival was significantly higher in the con-

Table 2. Penaeus plebejus. Omnibus ANOVA and planned contrasts $(\alpha=0.05)$ comparing average proportions of postlarvae remaining in 12 treatments. The different treatments

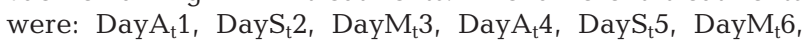
Night $A_{t} 1 ，$ Night $_{t} 2 ， \quad$ NightM $_{t} 3 ， \quad$ Night $_{t} 4$ ， Night $S_{t} 5$ and Night $M_{t} 6$, where $A_{t}, M_{t}$ and $S_{t}$ were trays with artificial macrophyte, bare mud or bare sand, respectively, over which postlarvae were initially released when they had either a choice of habitats to move between (1 to 3 ) or no choice (4 to 6 ) in either daytime (Day) or nighttime (Night) conditions. Contrasts 1 and 4 tested the hypotheses that DayA $A_{t} 1$ and DayA $_{t} 4>$ Day $\mathrm{S}_{\mathrm{t}} 2$ and DayM $\mathrm{H}_{\mathrm{t}}$, and Night $\mathrm{A}_{\mathrm{t}} 1$ and Night $\mathrm{A}_{\mathrm{t}} 4>$ Night $\mathrm{S}_{\mathrm{t}} 2$ and NightM $_{\mathrm{t}} 3$, respectively; . Contrasts 2 and 5 tested the hypotheses that DayS $2<$ DayS $_{\mathrm{t}} 5$ and Night $\mathrm{S}_{\mathrm{t}} 2<$ Night $S_{t} 5$, respectively. Contrasts 3 and 6 tested the hypotheses that DayM $_{t} 3<$ DayM $_{t} 6$ and NightM $_{t} 3<$ NightM $_{t} 6$, respectively. p-values in bold denote statistically significant differences; $\mathrm{n}=6$ for each treatment

\begin{tabular}{|c|c|c|c|c|}
\hline & $\mathrm{df}$ & MS & $F$ & $\mathrm{p}$ \\
\hline \multicolumn{5}{|c|}{ Omnibus ANOVA } \\
\hline Groups & 11 & 0.077 & 18.65 & $<0.05$ \\
\hline Residual & 60 & 0.004 & & \\
\hline Total & 71 & & & \\
\hline \multicolumn{5}{|c|}{ Planned contrasts } \\
\hline Contrast 1 & 1 & 0.79 & 189.85 & $<0.05$ \\
\hline Contrast 2 & 1 & 0.16 & 39.33 & $<0.05$ \\
\hline Contrast 3 & 1 & 0.15 & 36.57 & $<0.05$ \\
\hline Contrast 4 & 1 & 0.003 & 0.63 & $>0.05$ \\
\hline Contrast 5 & 1 & $8.33 \times 10^{-4}$ & 0.20 & $>0.05$ \\
\hline Contrast 6 & 1 & $2.08 \times 10^{-4}$ & 0.05 & $>0.05$ \\
\hline
\end{tabular}

Table 3. Penaeus plebejus. Two-way ANOVAs $(\alpha=0.05)$ comparing the average number of postlarvae surviving in different habitats in the presence and absence of predators. Metapenaeus macleayi, Acanthopagrus australis or Centropogon australis were used as predators in the laboratory and C. australis were used in the field. The habitats compared were simulated macrophyte, bare mud and bare sand. $\mathrm{p}$-values in bold denote statistically significant differences; $\mathrm{n}=6$ for each laboratory treatment and $\mathrm{n}=3$ for each field treatment

\begin{tabular}{|c|c|c|c|c|c|c|c|c|c|c|c|c|c|c|c|c|}
\hline & \multicolumn{4}{|c|}{ A. australis (laboratory) } & \multicolumn{4}{|c|}{ C. australis (laboratory) ${ }^{\mathrm{a}}$} & \multicolumn{4}{|c|}{ M. macleayi (laboratory) } & \multicolumn{4}{|c|}{ C. australis (field) } \\
\hline & $\mathrm{df}$ & MS & $F$ & $\mathrm{p}$ & $\mathrm{df}$ & MS & $F$ & $\mathrm{p}$ & $\mathrm{df}$ & MS & $F$ & $\mathrm{p}$ & $\mathrm{df}$ & MS & $F$ & $\mathrm{p}$ \\
\hline Predator $(\mathrm{P})$ & 1 & 3.87 & 744.6 & $<0.05$ & 1 & 35012 & 351.92 & $<0.05$ & 1 & 0.54 & 165.47 & $<0.05$ & 1 & 684.50 & 40.13 & $<0.05$ \\
\hline Habitat (H) & 2 & 0.11 & 20.98 & $<0.05$ & 2 & 891.85 & 8.96 & $<0.05$ & 2 & 0.00 & 0.06 & $>0.05$ & 2 & 134.00 & 7.86 & $<0.05$ \\
\hline $\mathrm{H} \times \mathrm{P}$ & 2 & 0.11 & 21.75 & $<0.05$ & 2 & 521.47 & 5.24 & $<0.05$ & 2 & 0.00 & 0.28 & $>0.05$ & 2 & 92.67 & 5.43 & $<0.05$ \\
\hline Residual & 30 & 0.005 & & & 30 & 99.49 & & & 30 & 0.00 & & & 12 & 17.06 & & \\
\hline Total & 35 & & & & 35 & & & & 35 & & & & 17 & & & \\
\hline
\end{tabular}




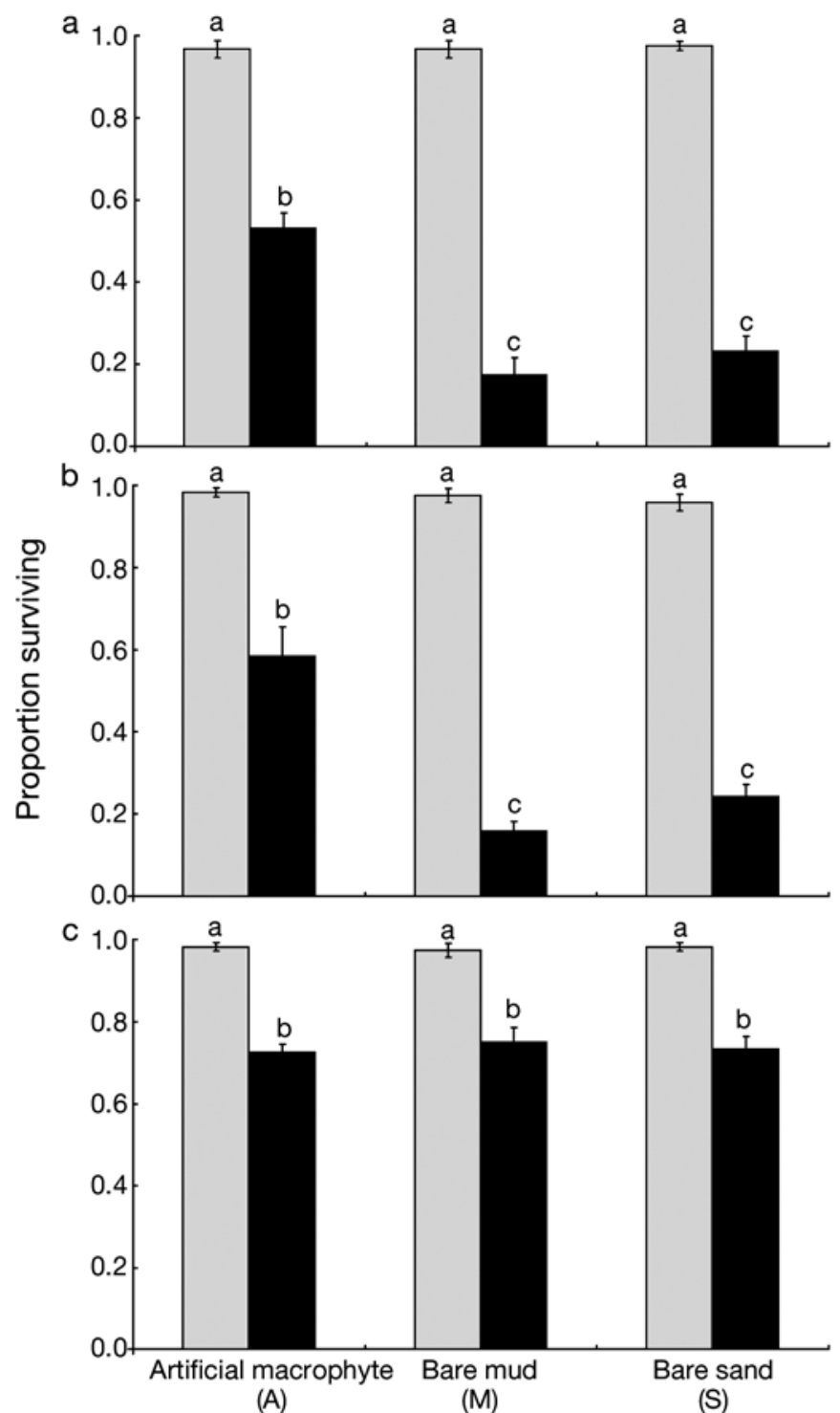

Fig. 3. Penaeus plebejus. Average $( \pm \mathrm{SE})$ proportion of postlarvae surviving in laboratory tanks with artificial macrophyte, bare mud or bare sand in absence (grey bars) and presence (black bars) of (a) Acanthopagrus australis, (b) Centropogon australis or (c) Metapenaeus macleayi as predators. Letters a, $\mathrm{b}$ and $\mathrm{c}(\mathrm{a}>\mathrm{b}>\mathrm{c})$ each represent groups of treatments that were statistically homogeneous according to Tukey's HSD tests $(\alpha=0.05, \mathrm{n}=6)$

trol tanks $(\sim 95 \%)$ compared with the experimental tanks $(\sim 75 \%)$, similar proportions of postlarvae survived across all habitats in the presence of predators (Table 3, Fig. 3c).

For the field-based experiments, variances were homogeneous amongst treatments (Cochran's test: $C=$ $0.26, \mathrm{n}=6, k=6, \mathrm{p}>0.05$ ) and there was a significant interaction between habitat and predator presence/ absence (Table 3). Tukey's HSD test showed that in the absence of Centropogon australis, all habitat types had similar proportions of postlarvae surviving within them (60 to $75 \%$ survival); however, in the presence of C. australis, significantly more postlarvae ( 60\%) survived in the macrophyte cages than in the sand and mud cages, which had similar survival rates $(\sim 30 \%$; Fig. 4).

\section{DISCUSSION}

Habitat complexity can affect ecological interactions directly by facilitating coexistence among competitors and influencing the success of predators and prey, or indirectly by influencing behavior and, thus, altering the outcome of interactions (Crowder \& Cooper 1982, Brown 1988). This study showed that complexity affects predation mortality and settling behavior in postlarval Penaeus plebejus.

\section{Habitat preference}

Penaeus plebejus did not show a preference for complex habitat during the night, with bare sand, bare mud and artificial macrophyte retaining similar numbers of postlarvae, regardless of whether alternative habitats were available. In contrast, when postlarvae were released into each habitat during the day and able to move between different habitats, higher proportions moved out of the non-complex habitats, sand and mud, than into the macrophyte habitat, suggesting a preference for macrophytes. A larger number of postlarvae left the bare habitats when the macrophyte habitat was also available compared with the number

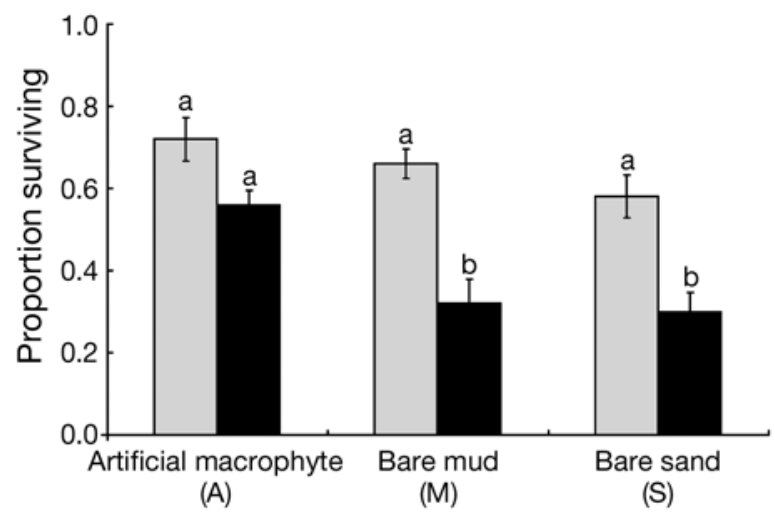

Fig. 4. Penaeus plebejus. Average $( \pm \mathrm{SE})$ proportion of postlarvae surviving in field cages with artificial macrophyte (A), bare mud $(\mathrm{M})$ or bare sand $(\mathrm{S})$ in the absence (grey bars) or presence (black bars) of Centropogon australis as predators. Letters $\mathrm{a}$ and $\mathrm{b}(\mathrm{a}>\mathrm{b})$ each represent groups of treatments that were statistically homogeneous according to Tukey's HSD tests $(\alpha=0.05, \mathrm{n}=3)$ 
that left the macrophyte habitat when it was the only one available, providing further evidence of a greater aversion to the bare habitats relative to the macrophyte habitat.

Several studies have attempted to examine habitat preference in other penaeids (e.g. Hughes 1966, Macia 2004, Gribble et al. 2007), but their methods tested for association with habitat rather than preference per se (see Underwood et al. 2004 for distinction). Key exceptions include studies on juvenile Penaeus aztecus, $P$. esculentus and $P$. semisulcatus, which display similar affinities for complex habitats as reported here, studies on juvenile $P$. setiferus, which exhibit no preference for either vegetated or un-vegetated habitat (Minello \& Zimmerman 1985, Hill \& Wassenberg 1993, Kenyon et al. 1997), and studies on juvenile Melicertus latisulcatus, which selected bare sand over vegetated habitat regardless of diel period (Tanner \& Deakin 2001). These varied results indicate that there is no common pattern among penaeids in general.

Habitat preference can play an important role in the survival of species as it can optimize the use of resources or limit negative interactions (Huey 1991, Real 1991, Rosenzweig 1991). For Penaeus plebejus, preference may reduce exposure to predators. Since many of the fish that feed on penaeids are visual daytime hunters (Brewer et al. 1995) and complex habitats can reduce their foraging efficiency (Heck \& Thoman 1981), postlarval $P$. plebejus may be selecting macrophyte beds when they are most at risk of predation (i.e. daytime). As penaeids increase in size, however, burrowing into sand may become a more effective means of predator avoidance than hiding among macrophytes (Hill \& Wassenberg 1993, Liu \& Loneragan 1997), resulting in an ontogenetic change in preference in favor of bare sand. Although this change may explain the distinct lack of preference for complex habitat in juvenile P. setiferus and Melicertus latisulcatus (Minello \& Zimmerman 1985, Tanner \& Deakin 2001), a number of other penaeids still select structured habitats over bare habitats as juveniles (Kenyon et al. 1997). Therefore, ontogenetic shifts in preference vary among penaeids and must be independently assessed for $P$. plebejus.

Although the diurnal habitat use patterns of postlarval Penaeus plebejus combined with our predation results suggest habitat preference is driven by predator avoidance, we cannot conclude that this is the only mechanism at play. Penaeid feeding activity is mainly nocturnal (Primavera \& Lebata 1995), with macrophytes and their epiphytes often contributing to penaeid diets (Kitting et al. 1984, Loneragan et al. 1997). Optimal foraging theory and a cost/benefit function incorporating predation risk and habitat profitability consequently predict that a postlarva will select macrophyte beds during the day to maximize energy intake per unit of time and simultaneously lower predation risk. During the night, however, reduced predator efficiency may preclude the need to shelter within macrophytes, thereby allowing the postlarva to forage in various habitats for alternative sources of food (MacArthur \& Pianka 1966, Sih 1980, Werner et al. 1983). Experiments examining selection of complex habitats by $P$. plebejus in the presence and absence of macrophyte-based food sources must be conducted to assess this theory. Another plausible explanation for the diurnal change in habitat use by postlarvae is an inability to perceive the visual cues required to select protective habitat in darkness leading to random settlement at night. However, penaeids are generally tactile and have well developed chemoreceptors (Zimmer-Faust 1989, Dall et al. 1990a), and these attributes may make them adept at perceiving surrounding habitat in the absence of visual reception.

\section{Predation mortality}

Predation on Peneaus plebejus postlarvae by Centropogon australis and Acanthopagrus australis was lower in artificial macrophytes compared with habitats without physical structure. These findings were consistent with studies on other members of Penaeidae (Minello \& Zimmerman 1985, Kenyon et al. 1995, Primavera 1997) and Caridea (Coen et al. 1981, Heck \& Thoman 1981). For penaeids and many other prey species, complex habitats limit predation by providing refuge or by reducing predatory foraging efficiency (Laprise \& Blaber 1992, Kenyon et al. 1995, Almany 2004). Postlarval P. plebejus were observed remaining motionless amongst vegetative structures in the presence of predators. This behavior may provide the best protection against predators during this life stage because burrowing into substrate to avoid detection by predators is not as prevalent in penaeid postlarvae (Hill \& Wassenberg 1993). Only 0.4 and $2.5 \%$ of the postlarvae used in our habitat preference and predation experiments, respectively, were observed burrowing.

When juvenile Metapenaeus macleayi were used as predators, the survival of Peneaus plebejus did not differ between complex and non-complex habitats. Where similar results have been recorded for other penaeids, aspects of the chosen predator's physiology and behavior may make it equally or more adept at detecting and capturing prey within complex habitats. Predation mortality in P. aztecus was unaffected by the presence of vegetative structure for predators that used non-visual chemosensory mechanisms to detect their prey (Minello \& Zimmerman 1983, Primavera 1997). Crustaceans such as M. macleayi possess sensi- 
tive chemoreceptors on their antennae, pereopods and mouthparts with an olfactory function (Zimmer-Faust 1989, Dall et al. 1990b). These receptors trigger foraging responses such as walking faster and probing into the substratum (Carr \& Derby 1986, Dall et al. 1990b) whenever prey are detected in the absence of visual cues. Compared with Acanthopagrus australis and Centropogon australis, whose chemosensory foraging abilities have not been previously documented, M. macleayi may have been less reliant on visual detection of prey due to their chemosensory abilities and, therefore, were able to forage effectively in macrophyte habitat. Predation by passive ambush predators, such as C. australis (Harmelin-Vivien \& Bouchon 1976) and A. australis (Shand et al. 2000), can also be significantly reduced by the presence of structure. In contrast, predators that chase their prey may be unaffected by complexity because they squeeze between structures and occupy the narrow crevices where prey attempt to hide (Primavera 1997). This active pursuit behavior has been documented in penaeid species (Racek 1959, Dall et al. 1990b) and may have added to the efficiency of $M$. macleayi as predators in complex habitats.

\section{Implications for stock enhancement}

Stock enhancement is one of the more expensive and least successful fishery management options available (Grimes 1998, Kellison et al. 2003). To reduce the ecological uncertainties that often limit its success, a candidate release species' optimal habitat must be known together with this habitat's carrying capacity and how to minimize losses through predation (Rothlisberg 1998). The present study provides important information on these elements for Peneaus plebejus.

Macrophyte beds provide optimal habitat for postlarval Peneaus plebejus and habitat structure can significantly reduce post-release predation mortality. Therefore, enhancement of $P$. plebejus must be undertaken in lakes and estuaries with extensive macrophyte beds. Experiments similar to those done here in a range of macrophyte habitats may help determine exactly which types of macrophytes best support the species. If $P$. plebejus is to be grown to larger sizes before release, habitat selection at these sizes must be investigated and the release habitats selected accordingly. Potential predators within a system should also be identified before enhancement. If predators such as Acanthopagrus australis and Centropogon australis are present at high densities relative to macrophyte cover, enhancement must be reassessed based on rigorous analyses that take into account potential losses through predation. If wild penaeids such as Metapenaeus macleayi exist at high densities, predation on released postlarvae may be significant across all habitats and restocking may only be viable if $P$. plebejus postlarvae are released into lakes and estuaries during the $M$. macleayi offshore migratory period or if $P$. plebejus are cultured to a size at which they will no longer be vulnerable to predation by large penaeids. If other potential predators are identified within target systems, experiments should be conducted to determine whether these predators will limit the survival of P. plebejus in the available habitat.

Stock enhancement efforts are slowly undergoing a paradigm shift from poorly investigated and hurried mass releases, to releases based on scientific theory and precautionary accountability (Leber 2002). This shift must continue to incorporate comprehensive pilot assessments of the ecological and life history patterns of candidate release species, previous investigations into the habitat characteristics of the targeted release sites and comparisons of the relative fitness of wild and stocked animals (Blankenship \& Leber 1995, Araki et al. 2007). Such studies will allow the financial costs and predicted ecological consequences of an enhancement program to be weighed against its projected economic, biological and social benefits and, therefore, assist in determining whether stock enhancement is a better response to fisheries problems than reduction of fishing effort or restoration of habitats.

Acknowledgements. This work was completed as part of a $\mathrm{PhD}$ candidature and supported in part by grants from the New South Wales (NSW) Recreational Saltwater Fishing Trust (no. L30), the Australian Research Council (no. LP0775000), and NSW Department of Primary Industries. It was carried out with University of New South Wales (UNSW) animal care and ethics approval (no. 06/88A). We thank A. Poore and S. Montgomery as well as staff and volunteers from UNSW and the NSW Department of Primary Industries for their assistance during the study. We are also grateful for the advice and feedback given by the anonymous reviewers.

\section{LITERATURE CITED}

Almany GR (2004) Does increased habitat complexity reduce predation and competition in coral reef fish assemblages? Oikos 106:275-284

Anderson CNK, Hsieh C, Sandin SA, Hewitt R and others (2008) Why fishing magnifies fluctuations in fish abundance. Nature 452:835-839

Araki H, Cooper B, Blouin MS (2007) Genetic effects of captive breeding cause a rapid, cumulative fitness decline in the wild. Science 318:100-103

Arnold SJ, Sellars MJ, Crocos PJ, Coman GJ (2005) Response of juvenile brown tiger shrimp (Penaeus esculentus) to intensive culture conditions in a flow through tank system with three-dimensional artificial substrate. Aquaculture 246:231-238

Bell JD, Westoby M (1986) Abundance of macrofauna in dense seagrass is due to habitat prference, not predation. Oecologia 68:205-209 
Blankenship HL, Leber KM (1995) A responsible approach to marine stock enhancement. Am Fish Soc Symp 15: 167-175

Brewer DT, Blaber SJM, Salini JP, Farmer MJ (1995) Feeding ecology of predatory fishes from Groote Eylandt in the Gulf of Carpentaria, Australia, with special reference to predation on penaeid prawns. Estuar Coast Shelf Sci 40: $577-600$

Brown JS (1988) Patch use as an indicator of habitat preference, predation risk, and competition. Behav Ecol Sociobiol 22:37-47

> Carr WES, Derby CD (1986) Chemically stimulated feeding behavior in marine animals. J Chem Ecol 12:989-1011

> Coen LD, Heck KL, Abele LG (1981) Experiments on competition and predation among shrimps of seagrass meadows. Ecology 62:1484-1493

Courtney AJ (2002) Developing indicators of recruitment and effective spawner stock levels in eastern king prawns (Penaeus plebejus). Queensland Department of Primary Industries, Brisbane

> Crowder LB, Cooper WE (1982) Habitat structural complexity and the interaction between bluegills and their prey. Ecology 63:1802-1813

Crowl TA, Townsend CR, McIntosh AR (1992) The impact of introduced brown and rainbow trout on native fish: the case of Australasia. Rev Fish Biol Fish 2:217-241

Dall W, Hill B, Rothlisberg P, Sharples D (1990a) The biology of the Penaeidae, Vol 27. Academic Press, London

Dall W, Hill B, Rothlisberg P, Sharples D (1990b) Food and feeding. In: Dall W, Hill B, Rothlisberg P, Sharples D (eds) The biology of the Penaeidae, Vol 27. Academic Press, London, p 314-332

Eades R, Steinkoenig E (1995) An evaluation of aquatic vegetation control by triploid grass carp in Virginia ponds. Am Fish Soc Symp 15:437-442

Einum S, Fleming IA (2001) Implications of stocking: ecological interactions between wild and released salmonids. Nord J Freshw Res 75:56-70

- Gribble NA, Wassenberg TJ, Burridge C (2007) Factors affecting the distribution of commercially exploited penaeid prawns (shrimp) (Decapod: Penaeidae) across the northern Great Barrier Reef, Australia. Fish Res 85: $174-185$

Grimes CB (1998) Marine stock enhancement: sound management or techno-arrogance? Fish Manag 23: 18-23

> Harmelin-Vivien ML, Bouchon C (1976) Feeding behavior of some carnivorous fishes (Serranidae and Scorpaenidae) from Tuléar (Madagascar). Mar Biol 37:329-340

Haywood MDE, Vance DJ, Loneragan NR (1995) Seagrass and algal beds as nursery habitats for tiger prawns (Penaeus semisulcatus and P. esculentus) in a tropical Australian estuary. Mar Biol 122:213-223

- Heck KL, Thoman TA (1981) Experiments on predator-prey interactions in vegetated aquatic habitats. J Exp Mar Biol Ecol 53:125-134

Heck KL, Thoman TA (1984) The nursery role of seagrass meadows in the upper reaches of the Chesapeake Bay. Estuaries 7:70-92

Hill BJ, Wassenberg TJ (1993) Why are some prawns found in seagrass? An experimental study of brown (Penaeus esculentus) and grooved ( $P$. semisulcatus) tiger prawns. Mar Freshw Res 44:221-227

Huey RB (1991) Physiological consequences of habitat selection. Am Nat 137:S91-S115

Hughes DA (1966) Investigations of the 'nursery areas' and habitat preferences of juvenile penaeid prawns in Mozambique. J Appl Ecol 3:349-354
Ives MC, Scandol JP (2007) A Bayesian analysis of NSW eastern king prawn stocks (Melicertus plebejus) using multiple model structures. Fish Res 84:314-327

Kellison GT, Eggleston DB, Taylor JC, Burke JS, Osborne JA (2003) Pilot evaluation of summer flounder stock enhancement potential using experimental ecology. Mar Ecol Prog Ser 250:263-278

Kenyon RA, Loneragan NR, Hughes JM (1995) Habitat type and light affect sheltering behavior of juvenile tiger prawns (Penaeus esculentus Haswell) and success rates of their fish predators. J Exp Mar Biol Ecol 192:87-105

- Kenyon RA, Loneragan NR, Hughes JM, Staples DJ (1997) Habitat type influences the microhabitat preference of juvenile tiger prawns (Penaeus esculentus Haswell). Estuar Coast Shelf Sci 45:393-403

> Kitting CL, Fry B, Morgan MD (1984) Detection of inconspicuous epiphytic algae supporting food webs in seagrass meadows. Oecologia 62:145-149

Laprise R, Blaber SJM (1992) Predation by Moses perch, Lutjanus russelli, and blue spotted trevally, Caranx bucculentus, on juvenile brown tiger prawn, Penaeus esculentus: effects of habitat structure and time of day. J Fish Biol 40:627-635

Leber KM (2002) Advances in marine stock enhancement: shifting emphasis to theory and accountability. In: Stickney RR, McVey JP (eds) Responsible marine aquaculture. CABI Publishing, Cambridge, MD, p 79-89

Liu H, Loneragan NR (1997) Size and time of day affect the response of postlarvae and early juvenile grooved tiger prawns Penaeus semisulcatus De Haan (Decapoda: Penaeidae) to natural and artificial seagrass in the laboratory. J Exp Mar Biol Ecol 211:263-277

Loneragan NR, Bunn SE, Kellaway DM (1997) Are mangroves and seagrasses sources of organic carbon for penaeid prawns in a tropical Australian estuary? A multiple stableisotope study. Mar Biol 130:289-300

Loneragan NR, Die DJ, Kailis R, Watson R, Preston NP (2007) Developing and assessing techniques for enhancing tropical Australian prawn fisheries and the feasibility of enhancing the brown tiger prawn (Penaeus esculentus) fishery in Exmouth Gulf. Fisheries Research and Development Corporation, Canberra

> MacArthur RH, Pianka ER (1966) On optimal use of a patchy environment. Am Nat 100:603-609

Macia A (2004) Juvenile penaeid shrimp density, spatial distribution and size composition in four adjacent habitats within a mangrove-fringed bay on Inhaca Island, Mozambique. Western Indian Ocean J Mar Sci 3:163-178

Minello TJ, Zimmerman RJ (1983) Fish predation on juvenile brown shrimp, Penaeus aztecus Ives: the effect of simulated Spartina structure on predation rates. J Exp Mar Biol Ecol 72:211-231

Minello TJ, Zimmerman RJ (1985) Differential selection for vegetative structure between juvenile brown shrimp (Penaeus aztecus) and white shrimp ( $P$. setiferus), and implications in predator-prey relationships. Estuar Coast Shelf Sci 20:707-716

Mnaya B, Mwangomo E, Wolanski E (2006) The influence of wetlands, decaying organic matter and stirring by wildlife on the dissolved oxygen concentration in eutrophicated water holes in Seronera River, Serengeti National Park, Tanzania. Wetlands Ecol Manag 14:421-425

Olabarria C, Underwood AJ, Chapman MG (2002) Appropriate experimental design to evaluate preferences for microhabitat: an example of preferences by species of microgastropods. Oecologia 132:159-166

Pikitch EK, Santora C, Babcock EA, Bakun A and others 
(2004) Ecosystem-based fishery management. Science 305:346-347

Primavera JH (1997) Fish predation on mangrove-associated penaeids: the role of structures and substrate. J Exp Mar Biol Ecol 215:205-216

Primavera JH, Lebata J (1995) Diel activity patterns in Metapenaeus and Penaeus juveniles. Hydrobiologia 295: 295-302

Racek AA (1959) Prawn investigations in eastern Australia. Res Bull State Fish NSW 6:1-57

Real LA (1991) Animal choice behavior and the evolution of cognitive architecture. Science 253:980-986

Rosenzweig ML (1991) Habitat selection and population interactions: the search for mechanism. Am Nat 137:S5-S28

Rothlisberg PC (1998) Aspects of penaeid biology and ecology of relevance to aquaculture: a review. Aquaculture 164: $49-65$

Rothlisberg PC, Preston NP, Loneragan NR, Die DJ, Poiner IR (1999) Approaches to reseeding penaeid prawns. In: Howell BR, Moksness E, Svasand T (eds) Stock enhancement and sea ranching. Fishing News Books, Oxford, p 365-378

Shand J, Chin SM, Harman AM, Moore S, Collin SP (2000) Variability in the location of the retinal ganglion cell area centralis is correlated with ontogenetic changes in feeding behavior in the black bream, Acanthopagrus butcheri (Sparidae, Teleostei). Brain Behav Evol 55:176-190

Sih A (1980) Optimal behavior: Can foragers balance two conflicting demands? Science 210:1041-1043

Editorial responsibility: Lisandro Benedetti-Cecchi, Pisa, Italy
Skilleter GA, Olds A, Loneragan NR, Zharikov Y (2005) The value of patches of intertidal seagrass to prawns depends on their proximity to mangroves. Mar Biol 147: 353-365

$\mathrm{Su}$ M, Liao IC (1999) Research and development of prawn stock enhancement in Taiwan. In: Howell BR, Moksness E, Svasand T (eds) Stock enhancement and sea ranching. Fishing News Books, Oxford, p 379-392

Tanner JE, Deakin S (2001) Active habitat selection for sand by juvenile western king prawns, Melicertus latisulcatus (Kishinouye). J Exp Mar Biol Ecol 261:199-209

Underwood AJ, Chapman MG, Crowe TP (2004) Identifying and understanding ecological preferences for habitat or prey. J Exp Mar Biol Ecol 300:161-187

Van Luijn F, Boers PCM, Lijklema L, Sweerts JPRA (1999) Nitrogen fluxes and processes in sandy and muddy sediments from a shallow eutrophic lake. Water Res 33:33-42

Werner EE, Gilliam JF, Hall DJ, Mittelbach GG (1983) An experimental test of the effects of predation risk on habitat use in fish. Ecology 64:1540-1548

Williams AB (1958) Substrates as a factor in shrimp distribution. Limnol Oceanogr 3:283-290

Young PC (1978) Moreton Bay, Queensland: a nursery area for juvenile penaeid prawns. Aust J Mar Freshw Res 29: $55-75$

Zimmer-Faust RK (1989) The relationship between chemoreception and foraging behavior in crustaceans. Limnol Oceanogr 34:1367-1374

Submitted: September 8, 2008; Accepted: January 19, 2009

Proofs received from author(s): March 27, 2009 